\title{
硬化歯車の高面圧時表面温度評価手法に関する基礎的研究
}

\author{
東嵪 康嘉*1，松下 直矢 ${ }^{* 2}$, 隅谷 悠司 ${ }^{* 3}$, 後藤 卓也 ${ }^{* 4}$, 田中 智之 ${ }^{* 5}$
}

\section{Basic study on measurement of surface temperature at high contact pressure by dynamic thermocouple with dissimilar hardened gears}

\author{
Yasuyoshi TOZAKI ${ }^{* 1}$, Naoya MATSUSHITA*2, \\ Yuuji SUMITANI ${ }^{* 3}$, Takuya GOTO ${ }^{* 4}$ and Tomoyuki TANAKA ${ }^{* 5}$ \\ ${ }^{*} 1,{ }_{2}, * 3,{ }^{*} 4$ Department of Mechanical Engineering, Kindai University \\ 3-4-1 Kowakae, Higashiosaka-shi, Osaka 577-8502, Japan \\ ${ }^{* 5}$ Engineering \& Development Group, Kanzaki Kokyukoki Mfg.Co.Ltd \\ 2-18-1 Inadera, Amagasaki-shi, Hyogo 661-0981, Japan
}

Received: 16 June 2017; Revised: 24 August 2017; Accepted: 28 September 2017

\begin{abstract}
Power transmission systems using gears require both large capacity and miniaturization. As a result, the gears used in power transmission need to be strong enough to withstand high loads and high engine speeds. Because surface damage and temperature are related, it is very important to know the surface temperature of gears in operation. However, measuring the surface temperature of gears in operation is difficult. As an effective means to measure the surface temperature, method of using dissimilar metals is known. The voltage proportional to surface temperature was produced by contacting dissimilar metals. This is known as Seebeck effect. The authors tried to use two simple ferrous metals. In this study, S55C (Carbon steel) and SUS316 (Stainless steel) were selected to dissimilar metals. Both dissimilar metals were heat-treated and surfaces were hardened. SUS316 was performed plasma carburizing process and S55C was performed induction hardening. As for the gear, it is known that the two or more teeth will mesh simultaneously. In order to remove the influence of the number of tooth in operation, the gear of two sheets were made into the one structure meshed by turns (combined lacked gear). When making the gear of two sheets into one structure meshed by turns. The experiments were operated on maximum condition of contact pressure $1.47 \mathrm{GPa}$ in a pitch point. As a result, surface temperature measured almost successfully by combined lacked gear by SUS316 plasma carburizing process and S55C induction hardening. When we compared the experimental values and the theoretical values using Blok's formula, surface temperatures on gear teeth values were largely same.
\end{abstract}

Keywords : Dynamic thermocouple, Surface temperature, Gear, Power transmission, Combined lacked gear

\section{1. 緒言}

歯車を用いた動力伝達装置への要求として，高強度・軽量・省スペース化などが挙げられる. これらの要求に 応えるためには，歯車を小型にし，高負荷・高回転数での運転が必要となる．高負荷・高回転数での歯車の運転

No.17-00272 [DOI:10.1299/transjsme.17-00272], J-STAGE Advance Publication date : 10 October, 2017

*1 正員, フェロー, 近畿大学 理工学部 機械工学科（一577-8502 大阪府東大阪市小若江 3-4-1)

*2 正員, 近畿大学大学院 総合理工学研究科 メカニックス系工学専攻

*3 近畿大学 理工学部 機械工学科

*4 学生員, 近畿大学 理工学部 機械工学科

*5 正員, (株) 神崎高級工機製作所 開発部（广 $661-0981$ 兵庫県尼崎市猪名寺 2-18-1）

E-mail of corresponding author: tozaki@mech.kindai.ac.jp 
は，歯車噛み合い部での大きな発熱が生じ，スカッフィングや焼付きと呼ばれる摩擦損傷を引き起こす。

スカッフィングは，歯面の油膜切れによって歯面が直接接触することで溶着を引き起こし，再び剥がされる ことで発生する損傷形態である.この現象が繰り返されることで歯面の状態が悪化し，歯車の振動や騒音, 効率 の低下などを引き起こす，そのため，スカッフィング強さに対する設計手法の確立が急務となる．このスカッ フィングに関しては様々な研究（藤井他，1989）(山田他, 1998）が行われている. 一般には歯面温度とスカッフ イング発生の間には関係があると言われている(藤田他，1988）。したがってスカッフィングの解明のためには, 歯車歯面の温度を計測することが重要となる。

歯面温度を計測する手法としては，微小熱電対を歯面に埋め込む方法(鄧他，1994）が最も簡易的であるが，多 くの測定点で計測することが困難であることや，歯面と熱電対の計測部が離れていることから実際の歯面温度と の誤差が問題となる．またサーモグラフィによる歯面温度の分布を計測する研究(近藤他, 1996)も行われている が，これも噛み合い部の計測を行うことができないため，スカッフィング限界值の指標とすることは難しい.

歯車の接触点を正確に測定する方法として, 動的熱電対法と呼ばれる熱電対の原理を応用した方法(横山他, 1971)(池条他，2009)が挙げられる．この方法は，歯車対の材質に異なる種類の金属を用いることで，歯車の噛み 合い部における発熱を起点とし, 生じる熱起電力を計測するものである.この計測法であれば, 歯車歯面の温度 を詳細に計測することが可能であるため，本研究ではこの手法を用いて計測を行う。

動的熱電対法における問題点としては, 別々の金属の歯車を用いるため, 両者の機械的強度や表面硬度に差が 生まれることが挙げられる. 池条らの研究(池条他, 2009)では歯車の材質に, 熱電対でよく用いられる, 鉄-コン スタンタンの組み合わせを採用することで計測を試みているが，コンスタンタンの強度が低いために一般的な歯 車の負荷条件での計測が行うことができない. 横山らの方法では(横山他, 1971)では, 図 1 に示すように硬質二 ッケルメッキと SNCM415 の浸炭焼入れとの組み合わせを用いており, 高負荷条件での計測が可能であるが, 二 ッケルと鋼の熱伝導率の差異や異種金属の接触となる箇所が歯面と歯車内部に存在し, 必ずしも真の表面温度と は言えない可能性がある事と, 表面温度解析する場合メッキ層を考慮する必要が生じる.

動的熱電対法では二歯噛み合い領域で発熱部が 2 箇所で発生し, その発熱量はすべり速度と荷重に比例する. すべり速度は噛み合い位置によって異なるため， 2 箇所で発生する熱起電力は異なる值を持つ. この異なる起電 力が合成された状態で計測すると， 2 点の噛み合い部の平均温度を測定することになる.

本研究ではこれらの問題を解決する方法として, 図 1 に示すように歯車の材質に単一素材となる SUS316 と S55C を採用し，それぞれにプラズマ浸炭, 高周波焼入れといった表面処理を施すことで硬化し, さらに非常に小 さな曲率半径のクラウニングを施すことにより高面圧条件（1.5GPa 程度）で試験を行えるようにした．また，二 歯噛み合い領域での並列回路の問題は，交互欠歯歯車(佐々木他，1966)を用いることで計測を可能とした.

[Yokoyama et al.]

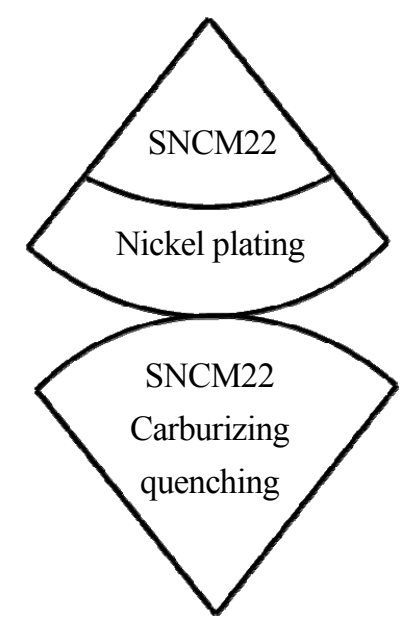

With nickel plating
[This research]

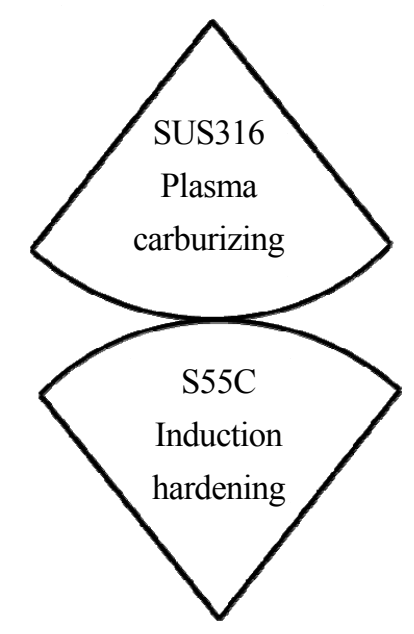

Without plating

Fig.1 A schematic diagram a comparison between this research and a conventional study. In this research, the thermoelectromotive force will be measured using dissimilar hardened metals without plating. 


\section{2. 熱起電力校正試験}

本研究では，メッキなどを用いず単一の素材でかつ硬化された異種金属を使用し歯車自体を熱電対とした動的 熱電対法による歯面温度測定を目的としている。しかし，実際に歯面温度を測定するには歯車材質による基準熱 起電力を調査する必要がある. 本項では, 最初に単一金属で硬化が可能で材料入手も容易な SUS316, S55C, SUJ2 の組合せ時の比較を行い, 熱起電力の最も大きな材料組合せに関する調査を行う. その後, 熱起電力が最も大き かった SUS316 と S55C の組み合わせにそれぞれプラズマ浸炭処理, 高周波焼入れの処理を行い, その組合せで の熱起電力を調査し, 動的熱電対法による温度変換式の作成について述べる. 加えて, 歯車歯面温度測定試験に おいて回転体から電気信号を取り出す際に使用するスリップリングの熱起電力への影響も調査する.

\section{$2 \cdot 1$ 材料選定試験}

図 2 に熱起電力校正試験の概略を示寸.なお, 温度誤差を抑えるために金属線と試験片の材質を同じにしたが, S55C に接続された金属線は，S60C を使用している。これは，金属線の規格に S55C が存在しないためであり， $\mathrm{S} 55 \mathrm{C}$ と比較的材質の近いものを選定している. 図 2 中にはスリップリングが記載されているが，材料選定試験 時はスリップリングを用いずに熱起電力の比較を行った.また, 材料選定試験時の材料には硬化を行っていない. 熱起電力を発生させるために, 試験片の接続部を容器に入れてその周囲をヒータで加熱し, 金属線の端点を氷水 につけ零接点とした. また, 試験片は油で満たされた容器に浸されており, 油の温度を温度計で測定することで, 熱起電力と温度の関係を対応付けた，なお，油の攪拌は常時行い温度を均一にするようにした。

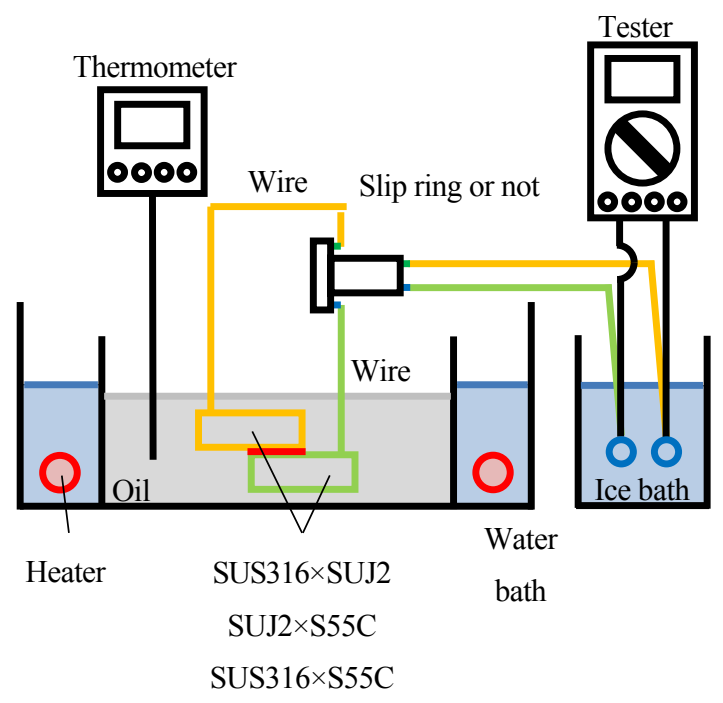

Fig.2 A schematic view of thermoelectromotive force calibration test. Steel wires of the same material properties are connected to test pieces of dissimilar metal, immersed in beakers filled with turbine oil, and then the ends of the wires are connected to a tester.

図 3 に作成した SUS316 の試験片を示す。また, 同様の試験片をS55C, SUJ2 で作製した.

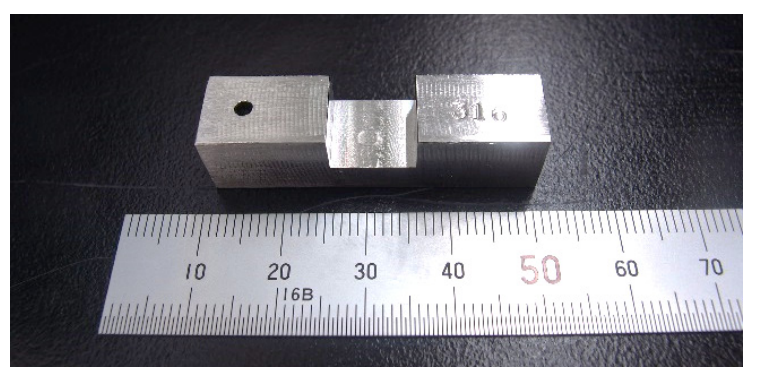

Fig.3 A test piece for thermoelectromotive force calibration test. 
図 4 に材料選定試験結果を示す.この結果より，SUS316 と S55C の組合せが最も大きな熱起電力を発生させる ことが分かった．ノイズの影響などを考えると少しでも大きな熱起電力の方が良いと考えられるので, SUS316 S55C の組合せを選択することにした.

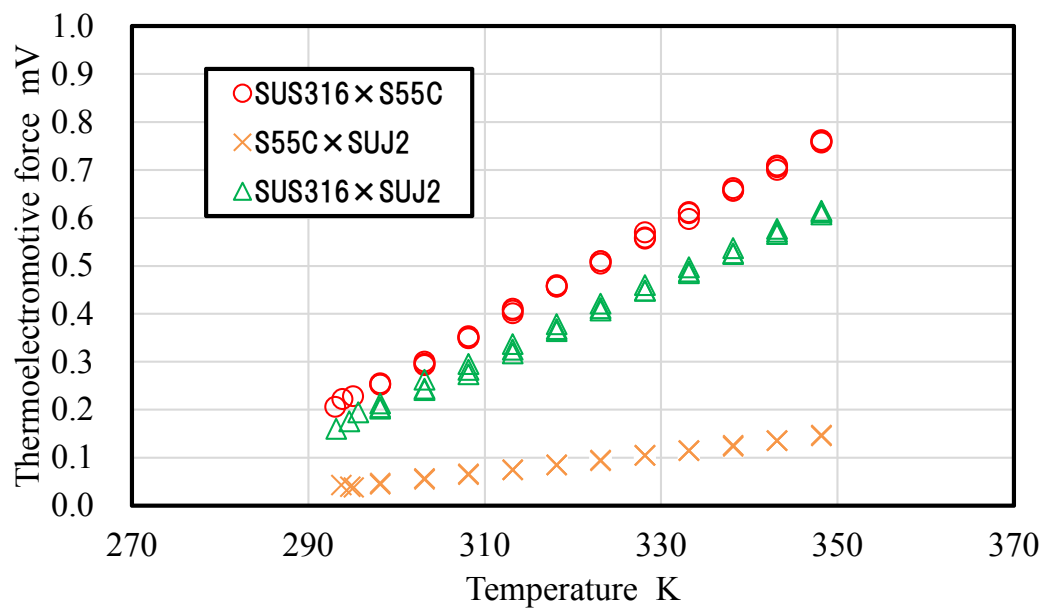

Fig.4 Material selection test results. It was found that the combination of SUS316 and S55C produce a large thermoelectromotive force.

図 5 にSUS316にプラズマ浸炭, S55C に高周波燒入れを施し，さらにスリップリングを装着した場合の熱起電 力計測結果を示す. 図 4 と図 5 の比較より，プラズマ浸炭もしくは高周波焼入れによる硬化処理の熱起電力への 影響, スリップリングを熱電対の閉回路内に接続することによる熱起電力への影響はないことが確認された．中 間金属の法則により，スリップリングは熱起電力の計測に影響を与えないと考えられるが，スリップリングを歯 車温度計測時と同等の温度状態に設置し, スリップリング周辺における温度差の影響が生じるか確認した. また, プラズマ浸炭を施した SUS316, 高周波焼入れを施した S55C の熱起電力と温度の関係は線形的に比例することが 確認された。この図から $T$ を接触部温度 $\mathrm{K}, V$ を熱起電力 $\mathrm{mV}, C$ を初期温度 $\mathrm{K}$ とすると

$$
T=101 V+C
$$

が導かれた. この近似式を用いることで動的熱電対法による計測において, 熱起電力からの温度変換を可能にし た.

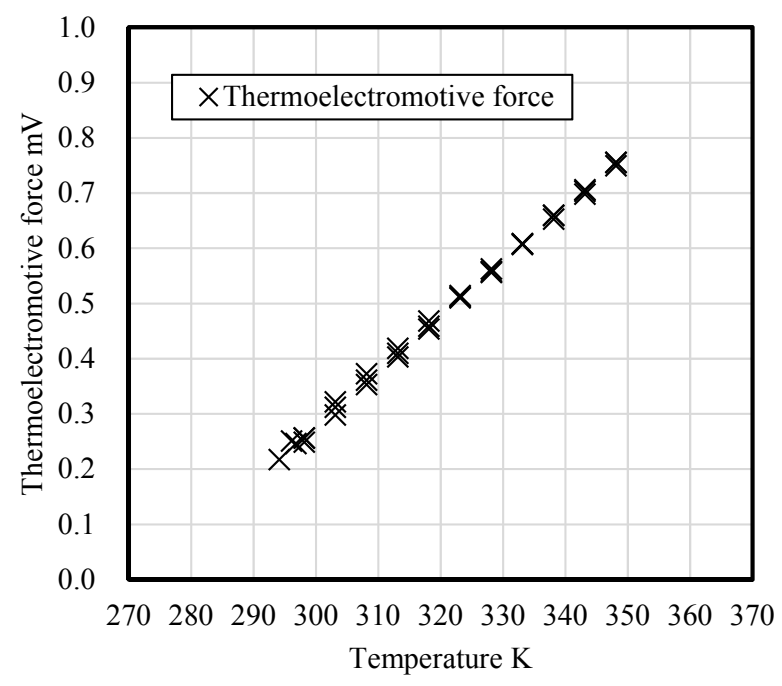

Fig.5 Results of thermoelctromotive force calibration test. Temperature conversion formula was derived for combinations of plasma carburized SUS316 and induction hardened S55C 
通常の熱電対である $\mathrm{T}$ 型絶縁熱電対（銅-コンスタンタン）を使用し，動的熱電対法との比較も行った. 図 6 のように歯車を噛み合わせ，接触点付近に $\mathrm{T}$ 型絶縁熱電対を装着し，接触点を加熱する. その後の動的熱電対法 による歯面温度と T 型絶縁熱電対による歯面温度を比較することで式（1）の有効性を確認する.

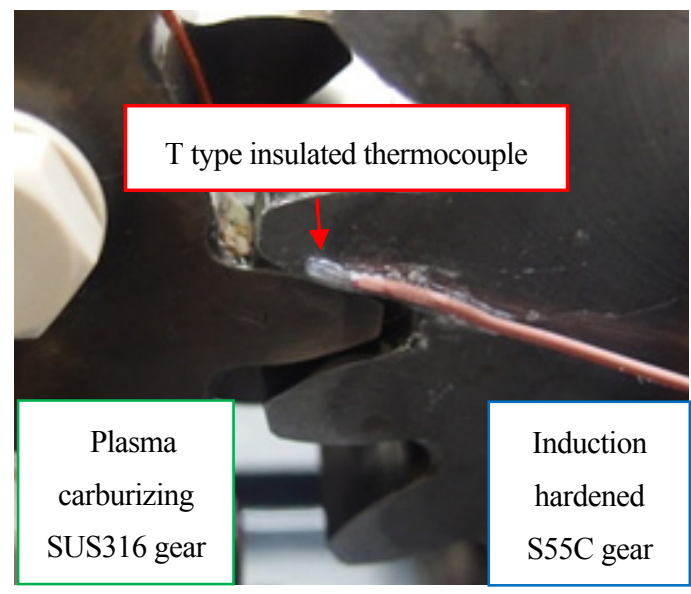

Fig.6 A photograph of comparative test with a $\mathrm{T}$ type insulated thermocouple. Gears were meshed, a $\mathrm{T}$ type insulated thermocouple was mounted near the contact point, and the contact point heated.

噛み合い部を $340 \mathrm{~K}$ 程度まで加熱し，自然冷却で低下していく温度を歯車対による熱電対と $\mathrm{T}$ 型絶縁熱電対で 計測し比較を行った. 図 7 に歯車対を用いた熱電対による熱起電力を式（1）に示した熱起電力-温度変換式を用 いて変換した温度と $\mathrm{T}$ 型絶縁熱電対による温度を比較したものを示す．両者の差は小さいために，式（1）に示 した熱起電力-温度変換式が実際の歯車対でも有効であると考えられる. 図 7 は室温 $\left(293 \mathrm{~K}, 20^{\circ} \mathrm{C}\right)$ からの温度変 化を示している.

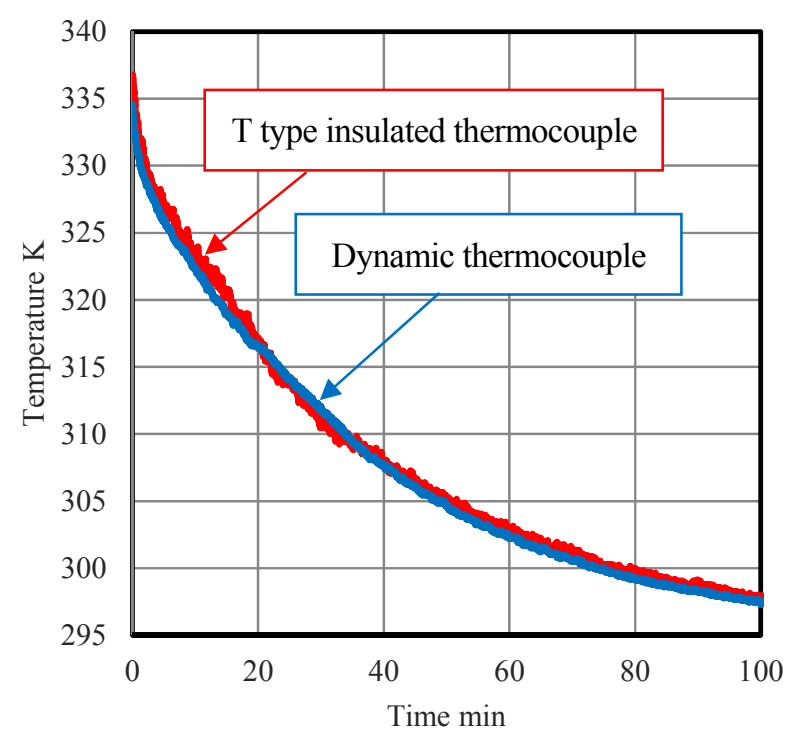

Fig.7 Results of thermoelectromotive force - temperature conversion formula verification test. The red curve shows the value of $\mathrm{T}$ type insulated thermocouple and the blue curve shows the value of dynamic thermocouple. Thermoelectromotive force - temperature conversion formula is confirmed to be effective. 


\section{3. 動的熱電対試験装置}

今回の研究では，SUS316にプラズマ浸炭，S55Cに高周波焼入れを施し，その組合せで熱電対とした．プラズ マ浸炭を施した SUS316 歯車を交互欠歯車とすることで，二歯噛み合い領域での計測を可能とした．さらに，歯 面にクラウニング加工を施すことにより，高面圧条件（1.5GPa 程度）での試験を可能とした．ちなみに，プラズ マ浸炭した SUS316 の表面硬さは, 1080HV で高周波焼入れした S55C の表面硬さは, 630HVであることを別途作 製した試験片にて確認を行った。

\section{$3 \cdot 1$ 試験歯車}

今回使用する駆動側歯車は, 図8に示すプラズマ浸炭SUS316交互欠組合せ歯車であり, 従動側歯車は図9に示す 高周波焼入れS55C歯車である，それらの歯車諸元を表1に示す，プラズマ浸炭SUS316交互欠組合せ歯車は，図8 に示すように交互に歯を欠けさせた2枚の歯車と絶縁材で構成されており, ボスが付いている歯車をA側歯車，ボ スがない歯車をB側歯車とする．組立て時には2枚の歯のピッチが合うような特殊治具を製作した，なお，これら の歯車には高面圧（約1.5GPa）で試験が行えるようクラウニング加工を施すことにした.
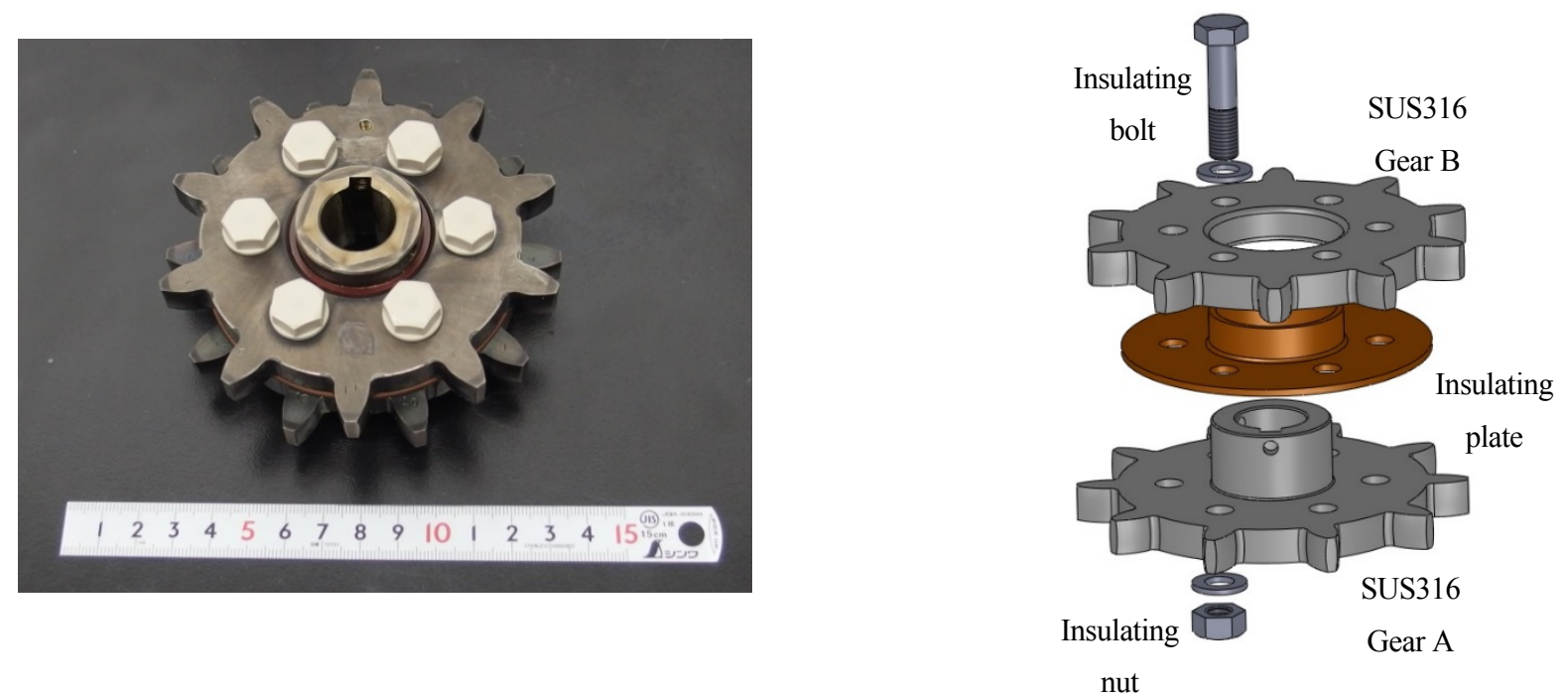

Fig.8 An external appearance of combined lacked gear. The plasma carburized SUS316 combined lacked gear consists of two gears and insulating plate alternately lacking teeth. The side A gear and the side B gear are combined by insulating bolts.

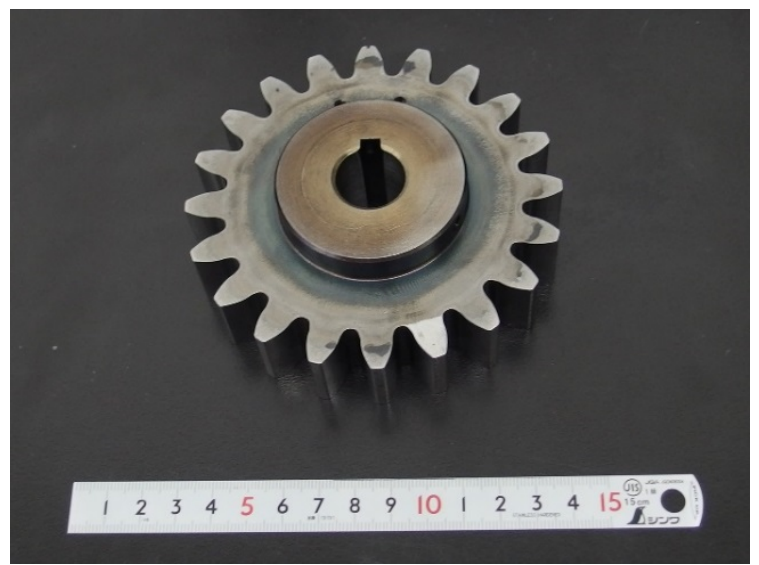

Fig.9 An appearance of the driven gear. The driven gear is the induction hardened S55C gear. This gear is not being machined specially. Tooth trace is straight. 
Table 1 Gear dimensions.

\begin{tabular}{c|c|c}
\hline \hline & $\begin{array}{c}\text { Plasma } \\
\text { carburized } \\
\text { SUS316 gear } \\
\text { (Drive) }\end{array}$ & $\begin{array}{c}\text { Induction } \\
\text { hardened } \\
\text { S55C gear } \\
\text { (Driven) }\end{array}$ \\
\hline Module & \multicolumn{2}{|c}{5} \\
\hline $\begin{array}{c}\text { Pressure angle } \\
\text { (deg) }\end{array}$ & \multicolumn{2}{|c}{20} \\
\hline Number of teeth & $20(10 \times 2)$ & 20 \\
\hline $\begin{array}{c}\text { Top diameter } \\
\text { (mm) }\end{array}$ & \multicolumn{2}{|c}{110} \\
\hline $\begin{array}{c}\text { Pitch diameter } \\
(\mathrm{mm})\end{array}$ & \multicolumn{2}{|c}{100}
\end{tabular}

\section{$3 \cdot 2$ 試験装置}

動的熱電対法と交互欠歯車を組み合わせた歯車歯面温度計測試験験装置を図10に示す．ギアードモータで駆動 し，パウダーブレーキで歯車に負荷トルクを与えた．駆動側歯車にプラズマ浸炭SUS316交互欠組合せ歯車，従動 側歯車に高周波焼入れS55C歯車を用い，セラミック玉軸受と樹脂カップリングを用いることでプラズマ浸炭 SUS316交互欠組合せ歯車のA側歯車とB側歯車を完全に絶縁し，軸端に取り付けたスリップリングを用いて回転 体から熱起電力を取り出しデータレコーダで計測した. なお, 試験条件は, 入力回転速度が $6,20,40,60 \mathrm{~min}^{-1}$, 負荷トルクが5, 10, 15, 20N・mの計16パターンで行った.

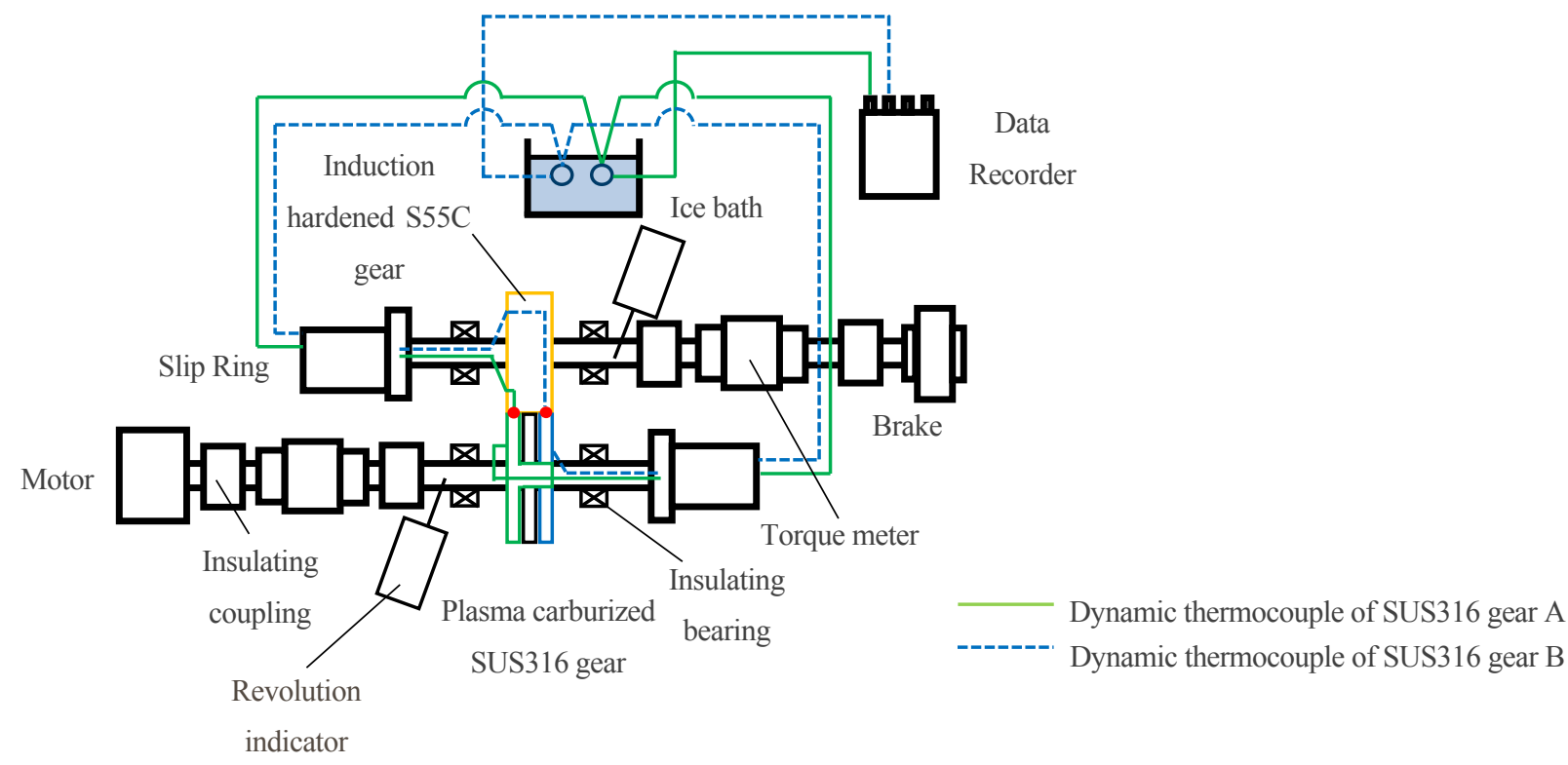

Fig. 10 A schematic view of test equipment. This figure shows the surface temperatures on gear teeth measuring test device combining a dynamic thermocouple and a combined lacked gear. It is driven by a geared motor and provides torque to gears with a powder brake. Using a plasma carburized SUS316 combined lacked gear for the drive gear, an induction hardened S55C gear for the driven gear, an insulating bearing and an insulating coupling, it fully insulates the side A gear and side B gear of the plasma carburized SUS316 combined lacked gear, uses the slip ring attached to the shaft end to remove thermoelectromotive force from the rotor, and measures it with a data recorder. 


\section{$3 \cdot 3$ クラウニング}

本研究では，高面圧時（約 $1.5 \mathrm{GPa}$ ）の試験を目的としているが，今回使用する試験機では負荷トルク $20 \mathrm{~N} ・ \mathrm{~m}$ 以上は負荷できない，そこで，プラズマ浸炭 SUS316 交互欠組合せ歯車にクラウニング加工を施すことで目標面 圧を達成させることを試みた. 図 11 は，クラウニング半径 $R_{y l}$ と最大へルツ面圧の関係を示したもので，へルツ の接触理論(Brewe and Hamrock,1977)によって得られる. 図11 からクラウニング半径 $R_{y l}$ が $42.5 \mathrm{~mm}$ 以下になると, ピッチ点での歯面の最大へルツ面圧は $1.5 \mathrm{GPa}$ 以上になることが分かる. プラズマ浸炭処理後の SUS316 交互欠組 合せ歯車のクラウニング半径 $R_{y 1}$ を計測したところ $46.2 \mathrm{~mm}$ であり， ピッチ点での歯面の最大ヘルツ面圧は $1.47 \mathrm{GPa}$ になる. 最大へルツ面圧を計算するときに用いた $R_{y l}$ と $R_{x l}$ の定義を図 12 に示す. 歯たけ方向の曲率半径 $R_{x I}$ は $17.1 \mathrm{~mm}$ とした．プラズマ浸炭 SUS316 の弾性係数は $193 \mathrm{GPa} ，$ 高周波焼入れ S55C の弾性係数は $206 \mathrm{GPa} の$ 值を用いて計算した.

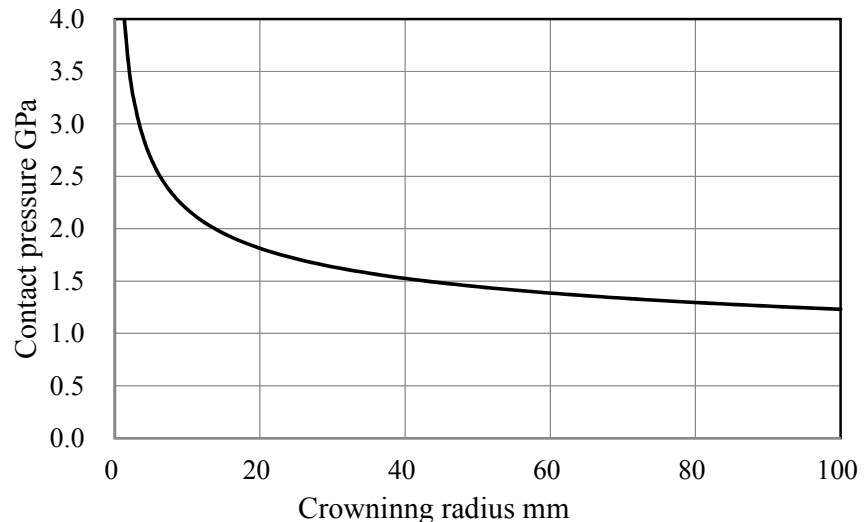

Fig. 11 The relationship between crowning radius $R_{x l}$ and maximum contact pressure. It was to do crowing grinding and enabled to experiment with high contact pressure.

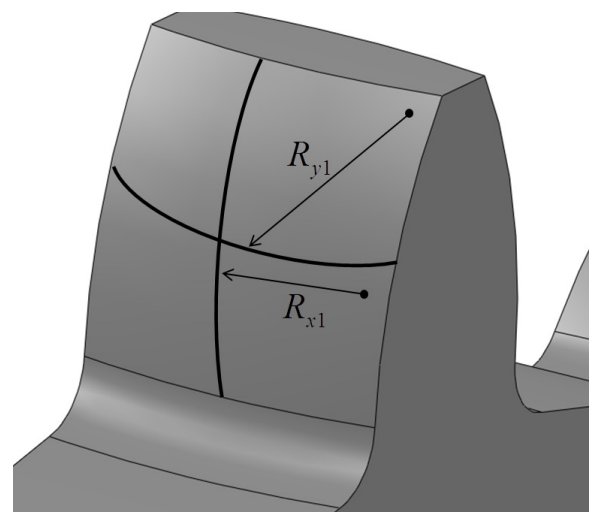

Fig. 12 A definition of radius $R_{y l}$ and $R_{x I} . R_{y l}$ and $R_{x l}$ are a coordinate which crosses at right angles. $R_{x l}$ is radius in the direction of tooth profile and $R_{y l}$ is crowning radius.

\section{$3 \cdot 4$ 歯面温度計測結果}

図 13 に入力回転速度が， $60 \mathrm{~min}^{-1}$ で入力トルクが $20 \mathrm{Nm}$ の時に歯車が 1 回転したときの歯面瞬間温度計測結果 を示す．図 13 より，歯先，ピッチ点，歯元における瞬間歯面温度上昇值が明確に現れているため，高面圧時にお ける瞬間歯面温度計測に成功したと考えられる．ただ，二歯噛み合い領域が一部でしか見受けられなかった．理 由としては，今回非常に小さな曲率半径のクラウニングを施したために，歯に直線部が無く歯のピッチが合うよ うにした特殊治具との接触が不十分でピッチ誤差が大きくなったものと考える．また，熱起電力はプラズマ浸炭 SUS316 交互欠組合せ歯車と高周波焼入れ S55C 歯車が接触することで生じる. 図 13 の噛み合い始めとなる歯先 や噛み合い終わりとなる歯元では, 接触と分離時のノイズを捉えるために, 高温が生じているように見える. 今回は安定して計測された 3 枚の連続歯の中の矢印で示した歯について考察を行うこととした．なお，Ice bath を基準設定温度 $\left(273 \mathrm{~K}, 0^{\circ} \mathrm{C}\right)$ として歯面瞬間温度計測を実施した。 

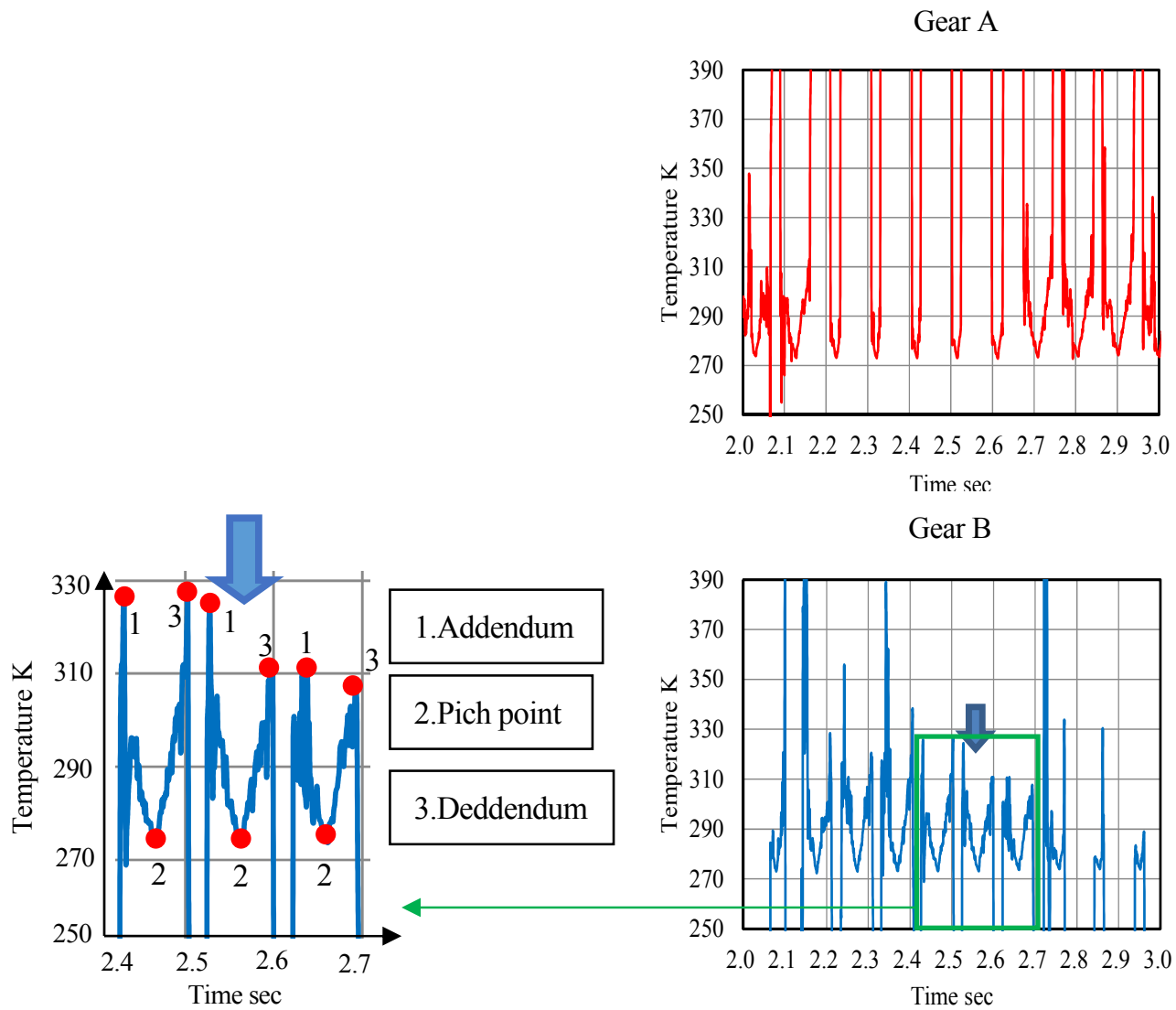

Gear B

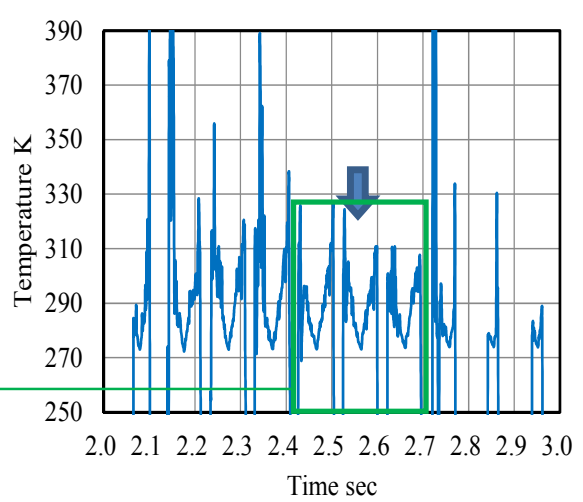

Fig. 13 The time series data of temperature. There are no slips at pitch point, so the temperature falls. The elevation on gear teeth appears at tooth tip and root. The rotating speed is $60 \mathrm{~min}^{-1}$ and input torque is $20 \mathrm{Nm}$ for an operating condition.

\section{4. 考察}

Blok が理論的に導出した瞬間歯面温度の式(Blok,1937)を用いて本試験で得られた瞬間歯面温度の実験值と比較 することにより，瞬間歯温度推定に関する考察を行う. 式（2）にBlok の瞬間歯面温度の式を示寸．今回の場合 単一金属を用いているため, Blokの式を用いることができる. 添え字の 1 はSUS316 を示し， 2 は S55C を示す.

$$
\theta=0.83 \times \frac{\mu P_{n}\left|v_{1}-v_{2}\right|}{\left(\sqrt{\lambda_{1} \gamma_{1} c_{1} v_{1}}+\sqrt{\lambda_{2} \gamma_{2} c_{2} v_{2}}\right) \sqrt{b^{\prime}}}
$$

\footnotetext{
$\mu$ : 歯面摩擦係数

$P_{n}:$ 単位法線荷重 $\mathrm{N} / \mathrm{m}$

$v$ : 接点周速度 $\mathrm{m} / \mathrm{s}$

$\lambda:$ 熱伝導率 $\mathrm{W} / \mathrm{m} \cdot \mathrm{K}$

$\gamma:$ 密度 $\mathrm{kg} / \mathrm{m}^{3}$

$c:$ 比熱 $\mathrm{J} / \mathrm{kg} \cdot \mathrm{K}$

$b^{\prime}:$ 接触半幅 $\mathrm{m}$
}

ここで, Blok の式において歯面摩擦係数 $\mu$ のみが，一義的に決まらないが今回は歯面の表面粗さ及び形成され る油膜厚さを考慮できる式(朝鍋, 松本，1986)を用いた. この場合式 (3) から式 (4) に示寸摩擦係数式で算出 する. 


$$
\begin{aligned}
& \mu=0.01(2.5 \log D+3.5) \\
& D=\frac{R z_{1}+R z_{2}}{h_{\min }}
\end{aligned}
$$

$\mu$ : 歯面摩擦係数

$D$ : 潤滑状態

$R z$ : 最大高さ粗さ $[\mu \mathrm{m}]$

$h_{\min }$ : 最小油膜厚さ $[\mu \mathrm{m}]$

今回使用寸る Blokによる瞬間歯面温度の式は線接触における瞬間歯面温度計算式である．本試験で用いている 歯車はクラウニング加工が施されており, 接触形態は点接触となる. そこで, Hertz の弾性接触理論(Johnson, 1985) に基づき接触面積が一定という仮定で近似をおこなった．図 14 に接触面近似の概要を示す．接触面積 $S$, 荷重 $W$ と接触長さ $2 a$ は変化しないと仮定し, 線接触状態の接触半幅 $b^{\prime}$ を新たに計算した. なお， $P_{n}$ は $W$ を $2 a$ で除し たものである．接触面積 $S$ が一定という近似のために，近似の前後における平均面圧の值と式 (2) における入熱 に相当する $\mu P_{n}\left|v_{1}-v_{2}\right|$ も同じ值となる. また, $a / b=3.03$ で接触部形状も長方形に近いと考えられるので今回の近 似は妥当と判断した。
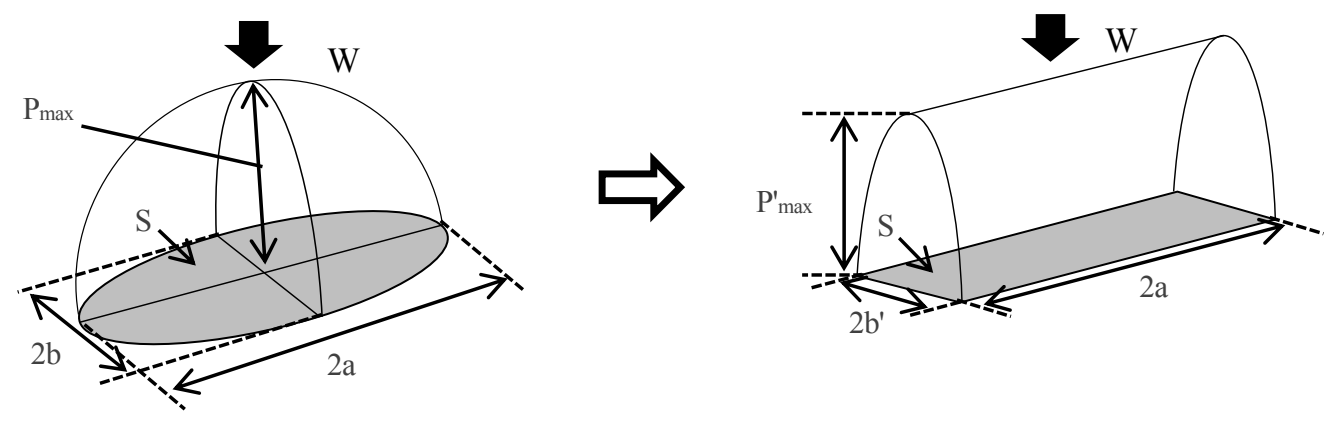

Fig. 14 An assumption of the contact surface approximation. Contact area $S$, normal load $W$ and axial length $2 a$ are assumed to be unchanged and new value of half contact width $b^{\prime}$ is calculated. By this assumption, a calculation of surface temperature is enabled.

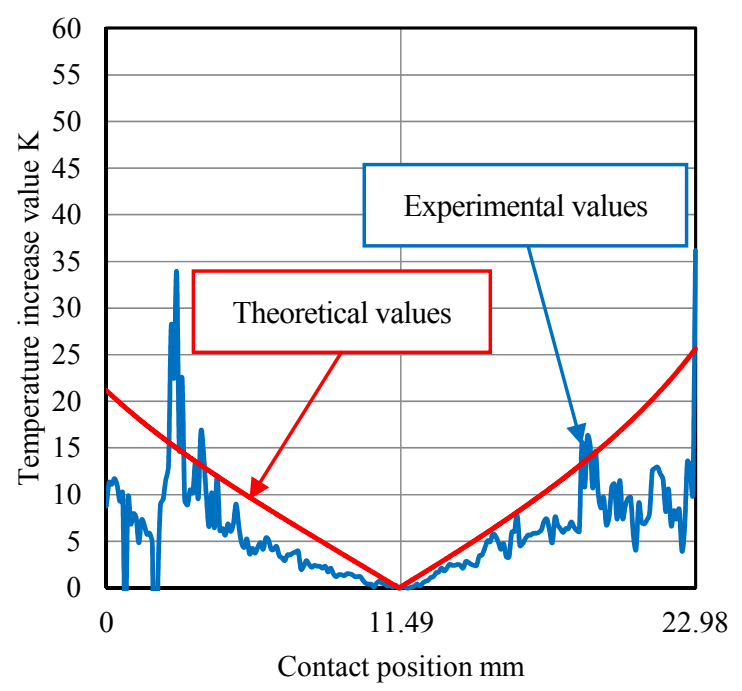

Fig. 15 A graph comparing the theoretical values for surface temperatures on gear teeth. The rotating speed is $20 \mathrm{~min}^{-1}$ and input torque is $10 \mathrm{Nm}$ for an operating condition. 


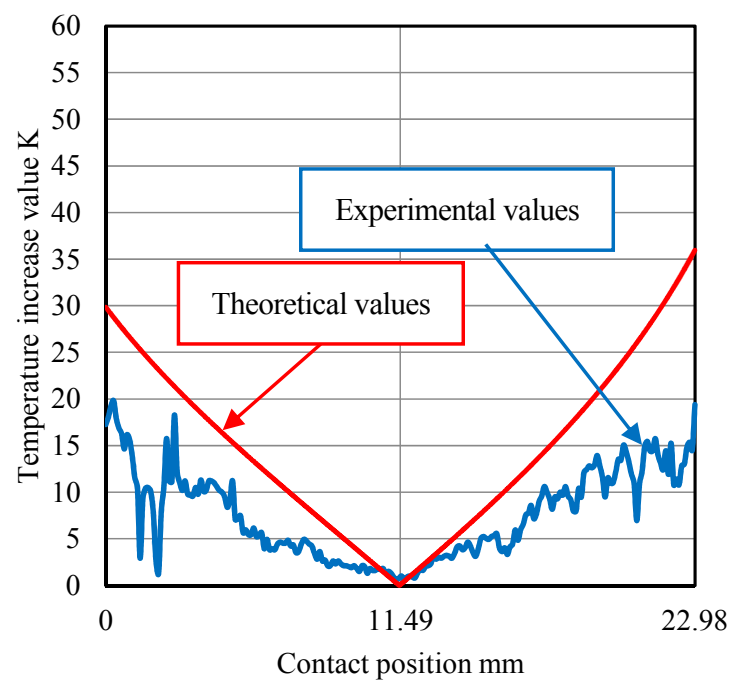

Fig. 16 A graph comparing the theoretical values for surface temperatures on gear teeth. The rotating speed is $20 \mathrm{~min}^{-1}$ and input torque is $20 \mathrm{Nm}$ for an operating condition.

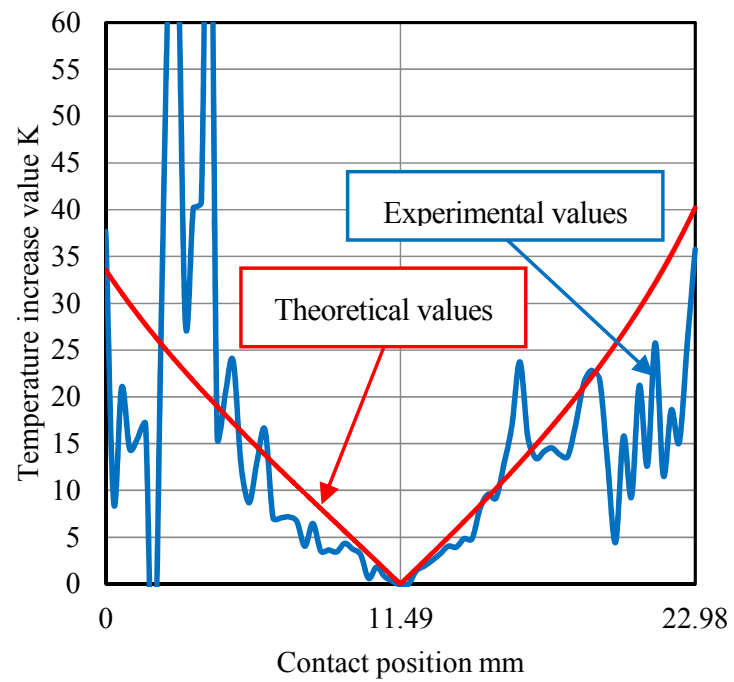

Fig. 17 A graph comparing the theoretical values for surface temperatures on gear teeth. The rotating speed is $60 \mathrm{~min}^{-1}$ and input torque is $10 \mathrm{Nm}$ for an operating condition. 


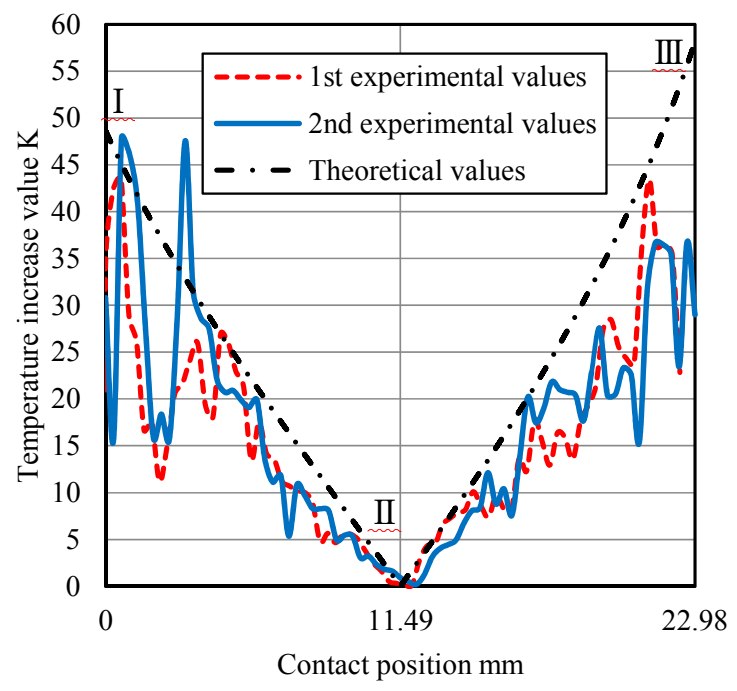

Fig. 18 A graph comparing the theoretical values for surface temperatures on gear teeth. The rotating speed is $60 \mathrm{~min}^{-1}$ and input torque is $20 \mathrm{Nm}$ for an operating condition.

図 13 に示した歯車 $\mathrm{B}$ の矢印箇所の試験結果を用いて計算結果との比較を行った. 図 13 の矢印で示した箇所の 歯車を用いて，異なる運転条件でも計算結果との比較を行った，その結果を，図 15，16，17に示す．噛み合い始 めや噛み合い終わりの点ではノイズに起因する誤差も確認されたが，噛み合い始めや噛み合い終わり以外では比 較的良く一致した。次に，今回試験を行った条件の中で最も㛜しい条件の $20 \mathrm{Nm}, 60 \mathrm{~min}^{-1}$ の条件で試験結果と 計算結果の比較を行ったが，良好に対応していることと再現性もあることが確認された.

なお, 試験は室温 $293 \mathrm{~K}$ の条件下で実施し,図 $15,16,17,18$ は基準設定温度 $\left(273 \mathrm{~K}, 0^{\circ} \mathrm{C}\right)$ からの上昇值を示した. 図 18 における I，II，IIIそれぞれの接触点での計算データを表 2 に示す. 使用した潤滑剤は ISO VG 10 に相当 し， $20^{\circ} \mathrm{C}$ における動粘度は $20.35 \mathrm{~mm}^{2} / \mathrm{s}$ ，そして粘度圧力係数は $18.6 \mathrm{GPa}^{-1}$ の值を用いて，油膜厚さは Dowson-Higginson (Johnson, 1970)の方程式を用いて計算した。なお, SUS316 と S55Cの表面粗さはそれぞれ Rz $=3.04 \mu \mathrm{m}, \mathrm{Rz}_{2}=3.57 \mu \mathrm{m}$ である. 図 19 において歯車 $\mathrm{A}$ と歯車 $\mathrm{B}$ の試験結果のデータを重ね合せたものを示す. 図 13 の矢印で示した箇所では歯車 $\mathrm{A}$ と歯車 $\mathrm{B}$ が同時に噛みあうことはなかった. この理由は先述したように小 さな曲率半径のクラウニング加工をおこなったためと考える.

Table 2 Calculated data.

\begin{tabular}{|c|c|c|c|c|c|c|c|c|c|c|}
\hline & \multirow{2}{*}{$h_{\min }[\mu \mathrm{m}]$} & \multirow{2}{*}{$D$} & \multirow{2}{*}{$\mu$} & \multirow{2}{*}{$P_{n}[\mathrm{~N} / \mathrm{m}]$} & $\lambda_{1}[\mathrm{~W} /(\mathrm{m} \cdot \mathrm{K})]$ & $\gamma_{I}\left[\mathrm{~kg} / \mathrm{m}^{3}\right]$ & $c_{I}[\mathrm{~J} /(\mathrm{kg} \cdot \mathrm{K})]$ & \multirow{2}{*}{$b^{\prime}[\mathrm{m}]$} & $v_{l}[\mathrm{~m} / \mathrm{s}]$ & \multirow{2}{*}{$\theta[\mathrm{K}]$} \\
\hline & & & & & $\lambda_{2}[\mathrm{~W} /(\mathrm{m} \cdot \mathrm{K})]$ & $\gamma_{2}\left[\mathrm{~kg} / \mathrm{m}^{3}\right]$ & $c_{2}[\mathrm{~J} /(\mathrm{kg} \cdot \mathrm{K})]$ & & $v_{2}[\mathrm{~m} / \mathrm{s}]$ & \\
\hline \multirow{2}{*}{ I } & \multirow{2}{*}{0.020} & \multirow{2}{*}{335.6} & \multirow{2}{*}{0.098} & \multirow{2}{*}{$310.9 \times 10^{3}$} & 16.3 & $7.82 \times 10^{3}$ & 494 & \multirow{2}{*}{$1.23 \times 10^{-4}$} & $36.4 \times 10^{-3}$ & \multirow{2}{*}{48.5} \\
\hline & & & & & 45.3 & $7.80 \times 10^{3}$ & 460 & & $185.5 \times 10^{-3}$ & \\
\hline \multirow{2}{*}{ II } & \multirow{2}{*}{0.025} & \multirow{2}{*}{261.4} & \multirow{2}{*}{0.095} & \multirow{2}{*}{$331.3 \times 10^{3}$} & 16.3 & $7.82 \times 10^{3}$ & 494 & \multirow{2}{*}{$1.70 \times 10^{-4}$} & $111 \times 10^{-3}$ & \multirow{2}{*}{0} \\
\hline & & & & & 45.3 & $7.80 \times 10^{3}$ & 460 & & $111 \times 10^{-3}$ & \\
\hline \multirow{2}{*}{ III } & \multirow{2}{*}{0.020} & \multirow{2}{*}{335.5} & \multirow{2}{*}{0.098} & \multirow{2}{*}{$310.9 \times 10^{3}$} & 16.3 & $7.82 \times 10^{3}$ & 494 & \multirow{2}{*}{$1.23 \times 10^{-4}$} & $185.6 \times 10^{-3}$ & \multirow{2}{*}{58.1} \\
\hline & & & & & 45.3 & $7.80 \times 10^{3}$ & 460 & & $36.4 \times 10^{-3}$ & \\
\hline
\end{tabular}




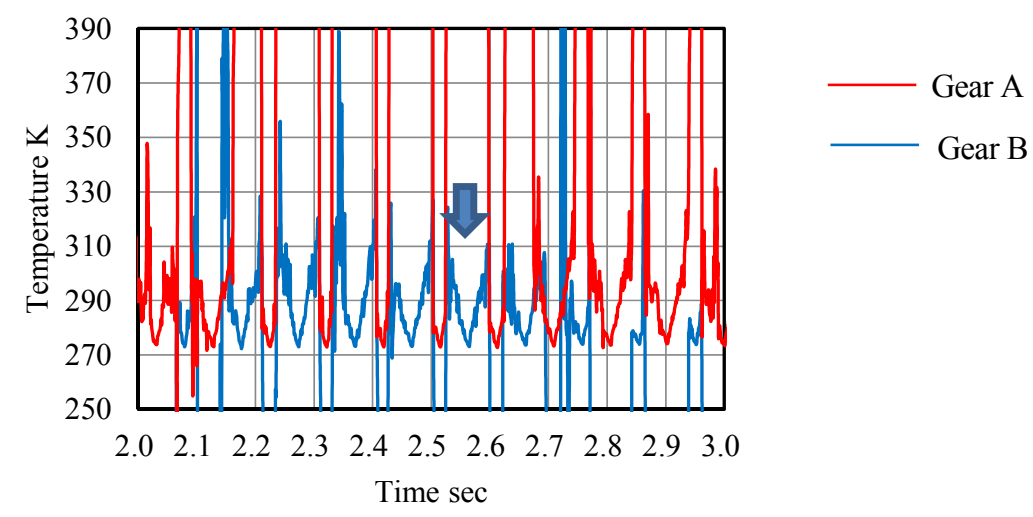

Fig. 19 A graph overlaying data of gear A and gear B. From this experimental result, double contact zone could not be found.

今回は高面圧下 $(1.47 \mathrm{GPa})$ での計測を行ったので, 試験前後の歯すじ曲線や歯面粗さの変化の調查を行った. 対象はプラズマ浸炭 SUS316 交互欠組合せ歯車とした. 交互欠組合せ歯車としたことで歯形測定装置での計測が できないため, メタクリレート樹脂による型取り計測を行った，そのために，歯車実体の上下位置が通常と逆に なる. 図 20 に試験前後の歯すじ形状すなわちクラウニング形状を示す.クラウニング半径 $R_{y l} 46 \mathrm{~mm}$ とすると, 図 20 の $0 \mathrm{~mm}$ の位置から $2 \mathrm{~mm}$ 移動すると約 $40 \mu \mathrm{m}$ 上方に曲線が移動するが，ほぼ一致している. 試験の前後でクラ ウニング半径は面圧に影響するほど変化はしていないと言える.また, 試験前後の表面粗さを図 21,22 に示すが, 変化は見られなかった，硬化処理をした歯車を用いて試験を行うことで，高面圧下の条件でも歯面の状態が変化 することなく歯面温度計測試験を行えることが確認できた。

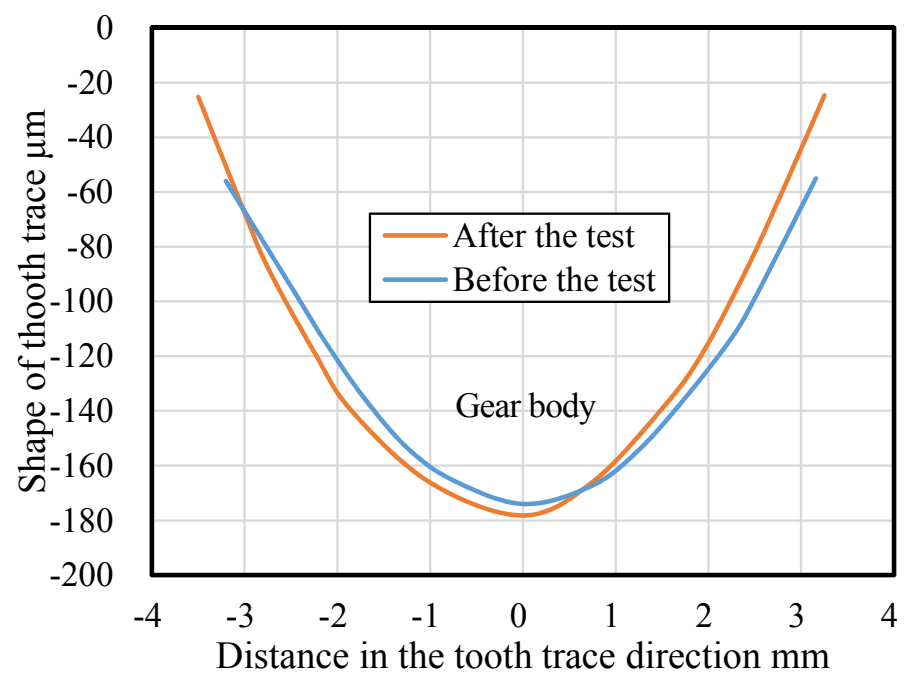

Fig. 20 Comparison of shape of tooth trace before and after the test. There is no large shape change before and after the test. 


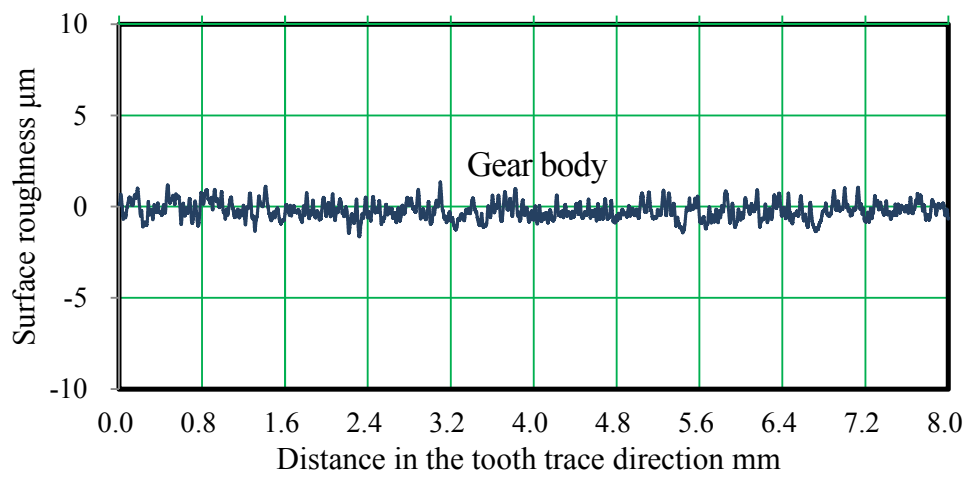

$$
\mathrm{R}_{\mathrm{a}}=0.43 \mu \mathrm{m}
$$

Fig. 21 Surface roughness measurement result before the test.

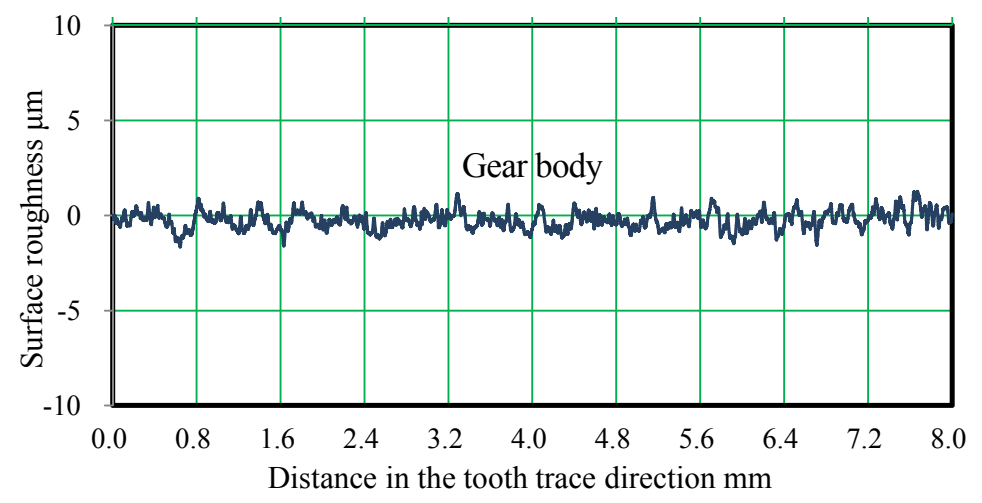

$\mathrm{R}_{\mathrm{a}}=0.43 \mu \mathrm{m}$

Fig. 22 Surface roughness measurement result after the test. Surface roughness did not change before and after the test.

\section{5. 結 言}

歯面温度が上昇しやすい高面圧下での歯面温度予測手法の確立を目指すことを目的とし，従来高面圧下での計 測に適用されていた硬質ニッケルメッキを用いる(横山他，1971)手法で生じる問題を回避するため，単一金属を 用いる手法に関する基礎的研究を行い下記の結論を得た.

（1）単一金属で硬化が可能で材料入手も容易な SUS316，S55C，SUJ2 の組合せ時の比較を行い，熱起電力の最 も大きな材料組合せに関する調査を行った，その結果，熱起電力が最も大きかった SUS316 と S55C の組み合わ せに高面圧での試験が可能なようにそれぞれプラズマ浸炭処理，高周波焼入れの処理を行い，その組合せでの熱 起電力を調査し，動的熱電対法による温度変換式の作成を行った。

（2）作成した温度変換式に基づき，動的熱電対法による高面圧下（1.47GPa）での計測を行った. Blok の式 (Blok,1937)に表面粗さと形成される油膜厚さを考慮して算出される歯面摩擦係数の式(朝鍋, 松本, 1986)を適用し た結果，試験結果と計算結果が良好に対応していることを見出した.

今後, 高面圧下で歯形や潤滑油などが歯面温度に与える影響に関して研究を進める可能性を見出すことができ た. 
謝辞

本研究は JSPS 科研費 $15 \mathrm{~K} 05774$ の助成を受けたもので, ここに謝辞を表する. また, 本研究で使用した潤滑 油は出光興産殿から供給を受けたことにも感謝致します.

\section{文献}

朝鍋定生，松本將，歯車の潤滑設計とトラブル対策，機械設計，Vol.30, No.6 (1986), pp.46-49.

Brewe, D. E., and Hamrock, B. J., Simplified solution for elliptical-contact deformation between two elastic solids,

Transaction of ASME Journal of Lubrication Technology Vol.99, No.4 (1977), pp.485-487.

Blok, H., Les temperatures de surface dans des conditions de graissage sous extreme pression, Proceedings of Second World Petroleum Congress, Paris, 3 (1937), pp.471-486 (in French).

鄧鋼, 丸山昇, 森川邦彦, 人見宣輝, 加藤正名, 熱電対による平歯車の歯面温度測定, 日本機械学会論文集 C 編,

Vol.60, No.570 (1994), pp.675-679.

藤井正浩，小幡文雄，吉田彰，松田 浩，藤田公明，平歯車におけるスコーリングの発生と進展に及ぼす歯形の

影響，日本機械学会論文集 C 編，Vol.55, No.512 (1989), pp.1017-1025.

藤田公明，小幡文雄，松尾浩平，歯車のスコーリング発生温度と潤滑，潤滑，Vol.33, No.4 (1988), pp.260-266.

池条清隆，永村和照，佐藤輝英，平歯車の動力損失に及ぼすトラクション油の影響，日本機械学会論文集 C 編,

Vol.75, No.757 (2009), pp.2560-2568.

Johnson, K.L., Contact mechanics (1985), pp.90-106, Cambridge Press.

Johnson, K.L., Regimes of elastohydrodynamic lubrication, Journal of Mechanical Engineering Science, Vol.12, No.1 (1970), pp.9-16.

近藤和宏，後藤貴博，永瀬和彦，サーモグラフィを用いた回転歯車歯面温度測定法に関する研究（第 1 報，同期 撮影法による基礎実験），日本機械学会論文集 C 編，Vol.62, No.604 (1996),pp.4603-4609.

佐々木外喜雄，岡村健二郎，小西忠孝，内田隆史，森武輔，歯車潤滑の基礎研究（第 8 報，歯面間油膜の形成之 その動的挙動の解析），日本機械学会論文集，Vol.32, No.240 (1966), pp.1296-1309.

山田寿夫, 山本史郎, 和田幸悦, スコーリング損傷に及ぼす潤滑油の影響, トライボロジスト, Vol.43, No.12 (1998), pp.1056-1063.

横山正明，石川二郎，林国一，動的熱電対法による平歯車の歯面温度測定，潤滑，Vol.16, No.7 (1971), pp.475-485.

\section{References}

Asanabe, S. and Matsumoto, S., Gear lubrication design and countermeasures for problems, Journal of Machine Design, Vol.30, No.6 (1986), pp.46-49 (in Japanese).

Brewe, D. E., and Hamrock, B. J., Simplified solution for elliptical-contact deformation between two elastic solids, Transaction of ASME Journal of Lubrication Technology Vol.99, No.4 (1977), pp.485-487.

Blok, H., Les temperatures de surface dans des conditions de graissage sous extreme pression, Proceedings of Second World Petroleum Congress, Paris, 3 (1937), pp.471-486 (in French).

Deng, G., Maruyama, N., Morikawa, K., Hitomi, N. and Kato, M., Measurement of surface temperature of spur gear teeth by thermocouples, Transactions of the Japan Society of Mechanical Engineers, Series C, Vol.60, No.570 (1994), pp.675-679 (in Japanese).

Fujii, M., Obata, F., Yoshida, A., Matsuda, H. and Fujita, K., Effects of teeth profile on scoring behavior in spur gears, Transactions of the Japan Society of Mechanical Engineers, Series C, Vol.55, No.512 (1989), pp.1017-1025 (in Japanese).

Fujita, K., Obata, F., Matsuo, K., Scuffing occurrence temperature and lubrication of gear pair, Journal of Japan Society of Lubrication Engineers, Vol.33, No.4 (1988), pp.260-266 (in Japanese). 
Ikejo, K., Nagamura, K. and Sato, T., Effect of traction oil on power loss of spur gear drive, Transactions of the Japan Society of Mechanical Engineers, Series C, Vol.75, No.757 (2009), pp.2560-2568 (in Japanese).

Johnson, K.L., Contact mechanics (1985), pp.90-106, Cambridge Press.

Johnson, K.L., Regimes of elastohydrodynamic lubrication, Journal of Mechanical Engineering Science, Vol.12, No.1 (1970), pp.9-16.

Kondoh, K., Gotoh, T. and Nagase, K., Study of measurement of the surface temperature of rotating toothed wheel by thermography (1.st Report, Basic study on synchronism photographing), Transactions of the Japan Society of Mechanical Engineers, Series C, Vol.62, No.604 (1996), pp.4603-4609 (in Japanese).

Sasaki, T., Okamura, K., Konishi, T., Uchida, T. and Mori, T., Fundamental research on gear lubrication (8th report, analysis on the formation of oil-film and its dynamic phenomena in mating gears), Transactions of the Japan Society of Mechanical Engineers, Series C, Part 3,Vol.32, No.240 (1966), pp.1296-1309 (in Japanese).

Yamada, H., Yamamoto, S. and Wada, K., Effect of lubricating oil on scoring of gear tooth, journal of Japanese Society of Tribologists Vol.43, No.12 (1998), pp.1056-1063 (in Japanese).

Yokoyama, M., Ishikawa, J. and Hayashi, K., Measurement of surface temperatures on gear teeth by dynamic thermocouple method, Journal of Society of Lubrication Engineers, Vol.16, No.7 (1971), pp.475-485 (in Japanese). 